\title{
IMPACT OF PHYSICOCHEMICAL FACTORS ON ZOOPLANKTON SPECIES RICHNESS AND ABUNDANCE IN BOMPAI-JAKARA CATCHMENT BASIN, KANO STATE, NORTHERN NIGERIA
}

\author{
${ }^{*}$ Imam, T.S. $^{1}$ and Balarabe, M.L. ${ }^{2}$ \\ ${ }^{1}$ Applied Biology Department, Bayero University, Kano, Nigeria. \\ 2Biological Sciences Department, Ahmadu Bello University, Zaria, Nigeria. \\ *Corrrespondence author: tijjanimam70@gmail.com
}

\begin{abstract}
A study on the impact of physicochemical factors on zooplankton species richness and abundance was carried out in Bompai-Jakara catchment for a period of two years (2009-2010). Six (6) sampling sites designated as $A, B, C, D, E$, and $F$ were chosen. Plankton net of $70 \mu m$ mesh size of $25 \mathrm{~cm}$ diameter was used in collecting grab samples of zooplanktons through vertical hauling. Physicochemical parameters such as temperature, pH, transparency, dissolved oxygen (DO), electrical conductivity (EC), and total dissolved solids (TDS) were determined using mercury-inglass thermometer, pH meter, Secchi disk, DO meter and EC/TDS meter respectively. Monthly sampling was conducted between January, 2009 and December, 2010. Result showed reduced zooplankton species richness between 2009 and 2010 of 33 spp. and 21 spp. respectively. Likewise there was observed reduction in zooplankton abundance with $289.07 \mathrm{org} / \mathrm{L}$ and $218.0 \mathrm{org} / \mathrm{L}$ in 2009 and 2010 respectively. But there was no significant difference at $P \leq 0.05$. There was significant negative correlation between zooplankton abundance and temperature, $\mathrm{pH}$ and TDS at $P \leq 0.05$. This study revealed that physicochemical fluctuations was negative impact on the zooplankton species richness and abundance, thus, the need for the government to establish catchment management agency in order to curtail the menace that disrupt the aquatic ecosystem.

Keywords: abundance, ecosystem, catchment basin, physicochemical, richness, zooplankton
\end{abstract}

\section{INTRODUCTION}

Water is used in many industrial processes and machines, as a chemical solvent. Zooplanktons are the animal component of plankton and form a vital link in aquatic food chains between microscopic photosynthetic algae and fish. They are also food for sea birds. Zooplanktons form major part of fish natural food as main source of proteins (Markovic, 2003). Zooplanktonic fauna are the major mode of energy transfer between the phytoplankton and the fish (Howick and Wilhm, 1984).

Zooplankton species richness refers to the number of species present in a given area/sample. Removing just one species from an ecosystem damages the flow of energy in that system (Verma and Agarwal, 2007). Zooplanktons respond rapidly to environmental changes, and hence their standing crop and species composition are more likely to indicate any damage in the aquatic milieu. River basins not only supply water for human, agricultural and industrial activities, but their floodplains and wetlands also have ecological values that are often overlooked (Smashkin et al., 2007; Imam et al., 2011).

Physicochemical parameters influence both vertical and horizontal migration of aquatic organisms. It affects their distribution, diversity and feeding. Physicochemical parameters of water are determined largely by the climate, geochemical and geomorphological conditions of catchment basin. Factors such as temperature, $\mathrm{pH}$, DO, transparency, and electrical conductivity form part of abiotic components of an aquatic ecosystem. When water temperature is outside tolerable range, abundance of zooplankton is affected directly (Abdullahi, 1998; Imam et al., 2011). High acidic or high alkaline $\mathrm{pH}$ could result to the death of aquatic organisms including zooplanktons. Zooplankton requires oxygen for energy metabolism. Sensitivity to low oxygen concentration differs between species, various life stages (eggs, larvae and adults), and different life processes including feeding, growth and reproduction (Imam et al., 2011). Water transparency influences vertical migration of zooplankton, which affects their diurnal rhythms (Verma and Agarwal, 2007).

Empirical evidence from the Kano city suggests that there is currently much reason for concern as industrial and domestic toxins are reaching dangerously high levels, thus, affecting the biodiversity in terms of aquatic species richness and diversity (Bichi, 1993).

This study aimed at assessing the impact of physicochemical fluctuations on zooplankton species richness and abundance in Bompai-Jakara catchment basin, Kano State. The findings obtained from this work hopefully will assist government policy making in proper understanding of the dynamics of the aquatic community in the catchment basin, since water is the only medium where aquatic community find shelter, food and make use of dissolved gases in it and reproduce without compromising need for changed environment. 


\section{MATERIALS AND METHODS Study Area}

Bompai-Jakara catchment basin (Latitude $12^{\circ} 40^{\prime}: 10^{\circ}$ $30^{\prime} \mathrm{N}$ and Longitude $7^{\circ} 40^{\prime}: 9^{\circ} 30^{\prime} \mathrm{E}$ ) is dendritic type of drainage basin formed as a result of convergence of wastewater streams, of which Jakara River carries municipal wastewater from the Kano old city district, while Getsi River carries industrial effluent from Bompai industrial estate, and the confluence drains the water into Wasai reservoir. The basin falls within the tropical wet and dry climate and northern limits of the tropical savanna zone of Nigeria. The climate of the basin is characterized by a cyclical migration of intertropical convergence zone (Kabiru, 2007).

During dry season humidity is low and evapotranspiration of $1587.5 \mathrm{~mm}$ was recorded (Ayoade and Oyelande, 1992). Many demands of exploitation exist, which include fishing activities conducted year round in the reservoir, recreational bathing as well as irrigation activities along the banks of the basin (Imam, 2010).

\section{Sampling Stations}

Six (6) sampling sites were chosen for the study, designated as A, B, C, D, E and F. Site A ( $11^{\circ}$ $\left.58^{\prime} .822^{\prime \prime} \mathrm{N}: 08^{\circ} 28^{\prime} .412^{\prime \prime} \mathrm{E}\right)$ is located on the Jakara River at Nomansland off Zungeru road. The water flows from the old city. It serves as the main drain for built up areas along the ways. Site B $\left(12^{\circ} 05^{\prime} .93^{\prime \prime} \mathrm{N}\right.$ : $8^{\circ} 37^{\prime} \mathrm{E}$ ) is located $100 \mathrm{~m}$ away from Kwana hudu bridge on the Getsi River. The river receives effluents from the Bompai industrial estate. Site C $\left(12^{\circ} 03^{\prime} \mathrm{N}\right.$ : $08^{\circ} 32^{\prime} \mathrm{E}$ ) is located within $5 \mathrm{~m}$ away from the confluence of rivers Jakara and Getsi. Site D $\left(12^{\circ}\right.$ $05^{\prime} \mathrm{N}$ : $08^{\circ} 05^{\prime} \mathrm{N}$ : $08^{0} 37^{\prime} \mathrm{E}$ ) is the entry point of the water from the tributary draining into the Wasai Reservoir. Site E $\left(12^{\circ} 07^{\prime} \mathrm{N}\right.$ : $\left.08^{\circ} 41^{\prime} \mathrm{E}\right)$ is situated $5 \mathrm{~m}$ away from the spillway of the dam, and site $\mathrm{F}\left(12^{\circ}\right.$ $08^{\prime} \mathrm{N}$ : $08^{\circ} 40^{\prime} \mathrm{E}$ ) is located $5 \mathrm{~m}$ away from the regulated outlet of the dam. The study was conducted between January, 2009 and December, 2010.

\section{Collection of Zooplanktonic Fauna}

Zooplankton grab samples were collected using plankton net mesh size $70 \mu \mathrm{m}$. It was towed vertically distance of one meter and hauled out of the water. The sample was collected into plastic bottle tied at the end of the net, and then was emptied into the sample bottle. Some of the samples were preserved with $4 \%$ formalin. The volume of the water that passed through the net was computed using the following formula (APHA, 2005):

$V=\pi r^{2} d$

Where: $V=$ volume of water filtered by the net, $r=$ radius of the mouth of the net

$\mathrm{d}=$ length of the haul.

\section{Concentration of Zooplankton Sample}

The collected sample from the plankton net was kept undisturbed for sedimentation to take place at one (1) hour settling per $\mathrm{mm}$ of column depth according to the protocol of APHA (2005). The supernatant was decanted in order to obtain desired volume. The concentrated sample was stored in a closed labeled $100 \mathrm{~mL}$ vial bottle for identification and counting of the zooplanktons.

\section{Zooplankton Enumeration and identification}

The zooplankton sample collected after condensation by sedimentation was taken for sorting and counting. Identification to genus level was performed using protocols of Kolb (1986) and Yamaguchi and Bell (2007). Zooplankton density (abundance) was computed using the following formula (APHA, 2005): No. $/ \mathrm{m}^{3}=\frac{\mathrm{C} \times \mathrm{V}^{\mathrm{I}}}{\mathrm{V}^{\mathrm{II}} \times \mathrm{V}^{\mathrm{III}}}$

Where: $\mathrm{C}=$ number of organisms counted, $\mathrm{V}^{\mathrm{I}}=$ volume of concentrated sample $(\mathrm{ml})$

$\mathrm{V}^{\mathrm{II}}=$ volume counted $(\mathrm{ml}), \mathrm{V}^{\mathrm{III}}=$ volume of grab sample $(\mathrm{ml})$

\section{Determination of Physicochemical Parameters of the Basin}

Surface Water Temperature: This was determined using mercury-in glass thermometer by dipping it into the water and allowed to stabilize for 5 seconds, removed and reading immediately recorded (APHA, 2005).

pH, Electrical Conductivity and Total dissolved Solids: These were measured using $\mathrm{pH} / \mathrm{EC} / \mathrm{TDS}$ meter (HANNA 3100 Model) by dipping the probes into the water until the screen showed a fixed reading as described by the manufacturers.

Dissolved Oxygen (DO): It was determined using DO meter (HANNA model HI 9146) in which the probe was inserted into the water until DO reading in $\mathrm{ppm}$ $(\mathrm{mg} / \mathrm{L})$ was recorded as described by the manufacturers.

5-Day Biochemical Oxygen Demand $\left(\mathrm{BOD}_{5}\right)$ : It was measured after collecting the samples into a labeled $250 \mathrm{~mL}$ brown bottle, kept in an incubator at Research laboratory at $21^{\circ} \mathrm{C}$ for 5 -days, then DO was measured again. $\mathrm{BOD}_{5}$ was obtained by subtracting the 5 -day $D O$ reading from the 0 -day $D O$ reading (APHA, 2005).

Transparency: The transparency of the water was measured using $20 \mathrm{~cm}$ diameter Secchi disk, which was dipped into the water till the disk disappeared and the depth was recorded, it was then dipped further and then withdrawn carefully and the depth at which it became visible was also recorded. Actual measurement was obtained by taking the average of the two readings (APHA, 2005).

\section{Statistical Analysis}

SPSS statistical software version 15 was employed in the analysis of data obtained, which include descriptive analyses like variables of zooplanktonic fauna, physicochemical parameters sum, mean and ranges. Likewise, Kendall's tau-b correlation was also utilised in the case of testing for any significant correlation between the variables (Lead Technologies, 2002). 


\section{RESULTS}

Table 1 shows the means and ranges of the physicochemical parameters of the basin in 2009 and 2010. There was an increase in temperature, $\mathrm{pH}, \mathrm{EC}, \mathrm{DO}$ and $\mathrm{BOD}_{5}$ from $24.3-24.9^{\circ} \mathrm{C}, 7.9-8.0,5.5-5.7 \mathrm{mg} / \mathrm{L}$ and $2.4-$ $2.63 \mathrm{mg} / \mathrm{L}$ respectively. The result of this study shows significant negative correlation between zooplankton density and temperature, $\mathrm{pH}$ and TDS at $\mathrm{P} \leq 0.05$ (Table 2). Figure 1 illustrates mean zooplankton densities of 2009 and 2010, with 2009 having relatively higher abundance of 289.07org/L as opposed to 218.0org/L in 2010 . Figure 2 shows the zooplankton richness, in which 2009 had relatively higher zooplankton species richness of 33 as compared with 21 species in 2010. Figure 3 shows the result of zooplanktonic taxa percentage composition in 2009 and 2010. Protozoa is the taxonomic group with highest percent composition in both years with $39.4 \%$ and $33.3 \%$ in 2009 and 2010 respectively. Mysida and Trematoda are the group that were not recovered in 2010, while Tunicata and Chaetognatha were the two emerging groups not previously recovered in 2009 but isolated in 2010.

There was no significant difference between the variation in physicochemical parameters in both years at $P \leq 0.05$, but there was significant difference between zooplankton abundance between 2009 and 2010, although no significant difference was observed between zooplankton species richness recorded in 2009 and 2010 at $\mathrm{P} \leq 0.05$.

Table 1: Mean Physicochemical Parameters in 2009 and 2010 of Bompai-Jakara Catchment Basin, Kano State, Nigeria.

\begin{tabular}{|c|c|c|c|c|}
\hline Parameter & $\begin{array}{c}2009 \\
\text { Mean } \pm \text { SD* }\end{array}$ & $\begin{array}{c}2010 \\
\text { Mean } \pm \text { SD* }\end{array}$ & $\begin{array}{c}\text { Range } \\
\text { Min - Max }\end{array}$ & $\begin{array}{l}\text { Standard } \\
\text { Limit }\end{array}$ \\
\hline Temperatue $\left({ }^{0} \mathrm{C}\right)$ & $24.3 \pm 0.75$ & $24.9 \pm 0.731$ & $23.3-26.1$ & $\begin{array}{c}<40^{\circ} \mathrm{C} \\
\text { (FEPA, 1991; } \\
\text { WHO, 1999) }\end{array}$ \\
\hline $\mathrm{Ph}$ & $7.9 \pm 3.56$ & $8 \pm 0.551$ & $7-8.5$ & $\begin{array}{c}6.0-9.0 \\
\text { (FEPA, 1991; } \\
\text { WHO, 1999) }\end{array}$ \\
\hline Transparency $(\mathrm{cm})$ & $32.5 \pm 21.4$ & $32.5 \pm 21.91$ & $14-61.6$ & $\begin{array}{c}20-40 \\
\text { (Chackroff, 1978) }\end{array}$ \\
\hline $\mathrm{EC}(\mu \mathrm{S} / \mathrm{cm})$ & $1977 \pm 133$ & $2035.5 \pm 746.54$ & $1265-2839.2$ & $\begin{array}{l}2000 \\
\text { (FEPA, 1991; } \\
\text { WHO, 1999) }\end{array}$ \\
\hline $\mathrm{TDS}(\mathrm{mg} / \mathrm{L})$ & $1285 \pm 457.8$ & $1323.12 \pm 485.3$ & $822.3-1845.5$ & $\begin{array}{c}<600 \\
\text { (Pandey, 1997) }\end{array}$ \\
\hline $\mathrm{DO}(\mathrm{mg} / \mathrm{L})$ & $5.5 \pm 1.425$ & $5.7 \pm 0.781$ & $3.9-7.6$ & $\begin{array}{c}5.0-7.0 \\
(\text { FEPA, 1991; } \\
\text { WHO, 1999) }\end{array}$ \\
\hline $\begin{array}{l}\text { 5-day BOD } \\
(\mathrm{mg} / \mathrm{L})\end{array}$ & $2.4 \pm 9.253$ & $2.63 \pm 0.333$ & $1.96-3.1$ & $\begin{array}{c}<4.0 \\
\text { (FEPA, 1991; } \\
\text { WHO, 1999) }\end{array}$ \\
\hline
\end{tabular}

Table 2: Kendall's tau-b Corelation between Zooplankton Density and Physicochemical Parameters in 2009 and 2010.

\begin{tabular}{|c|c|c|c|}
\hline \multirow[t]{2}{*}{ Parameter } & \multicolumn{2}{|c|}{ Zooplankton Density (organisms/L) } & \multirow[b]{2}{*}{ Overall } \\
\hline & & 2010 & \\
\hline Temperature $\left({ }^{\circ} \mathrm{C}\right)$ & $-0.787 *$ & $-0.779 *$ & $-0.777 *$ \\
\hline $\mathrm{pH}$ & $-0.864 *$ & $-0.643 *$ & $-0.782 *$ \\
\hline Transparency (cm) & 0.488 & 0.481 & 0.423 \\
\hline $\mathrm{EC}(\mu \mathrm{S} / \mathrm{cm})$ & 0.488 & 0.481 & 0.400 \\
\hline TDS (mg/L) & $-0.803 *$ & $-0.702 *$ & $-0.821 *$ \\
\hline $\mathrm{DO}(\mathrm{mg} / \mathrm{L})$ & -0.509 & 0.484 & 0.200 \\
\hline $\mathrm{BOD}_{5}(\mathrm{mg} / \mathrm{L})$ & 0.036 & -0.035 & 0.223 \\
\hline
\end{tabular}

*Significant negative correlation at $\mathrm{P} \leq 0.05$. 


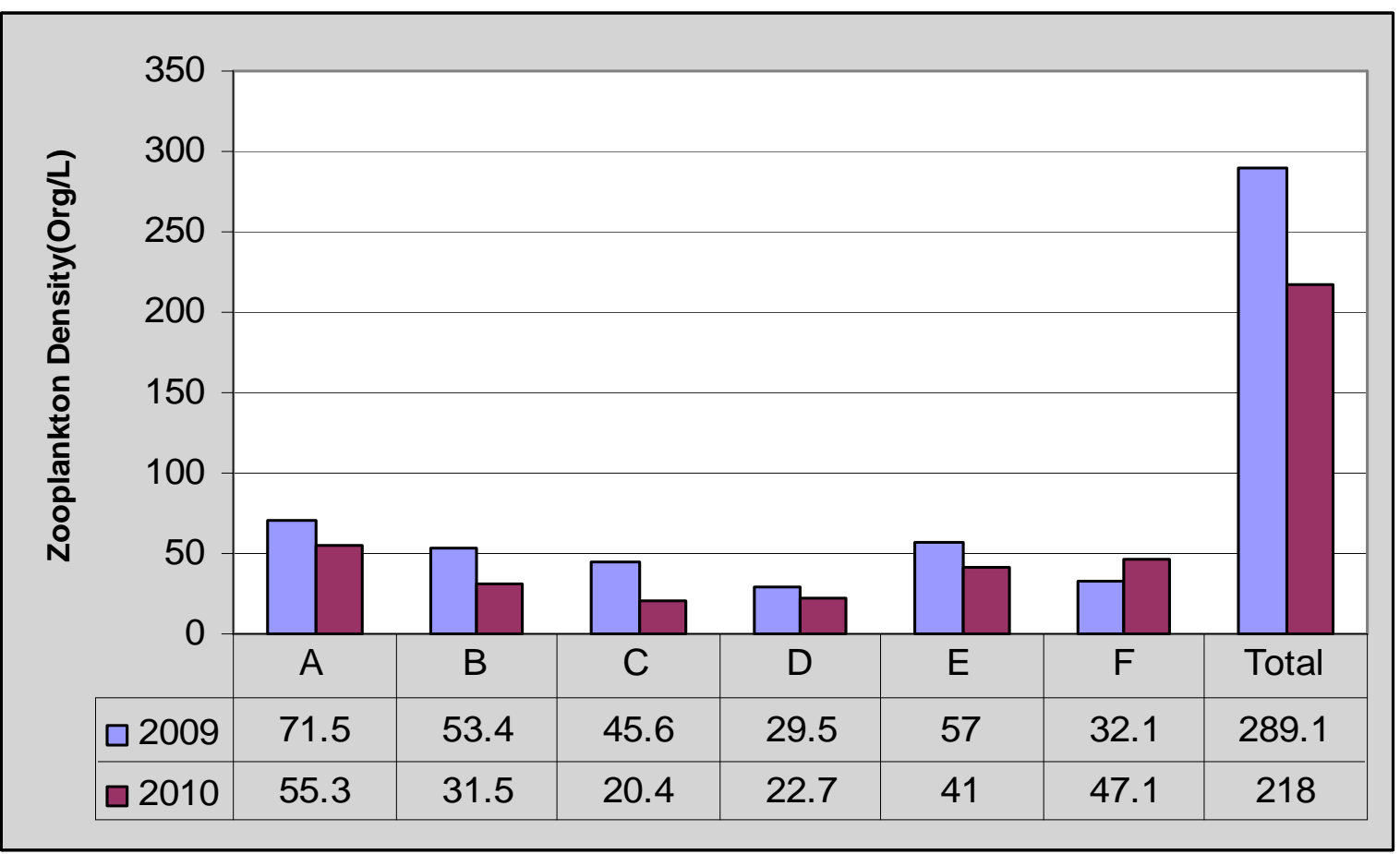

Figure 1: Mean Zooplankton Densities in 2009 and 2010 in Bompai-Jakara Catchment Basin, Kano.

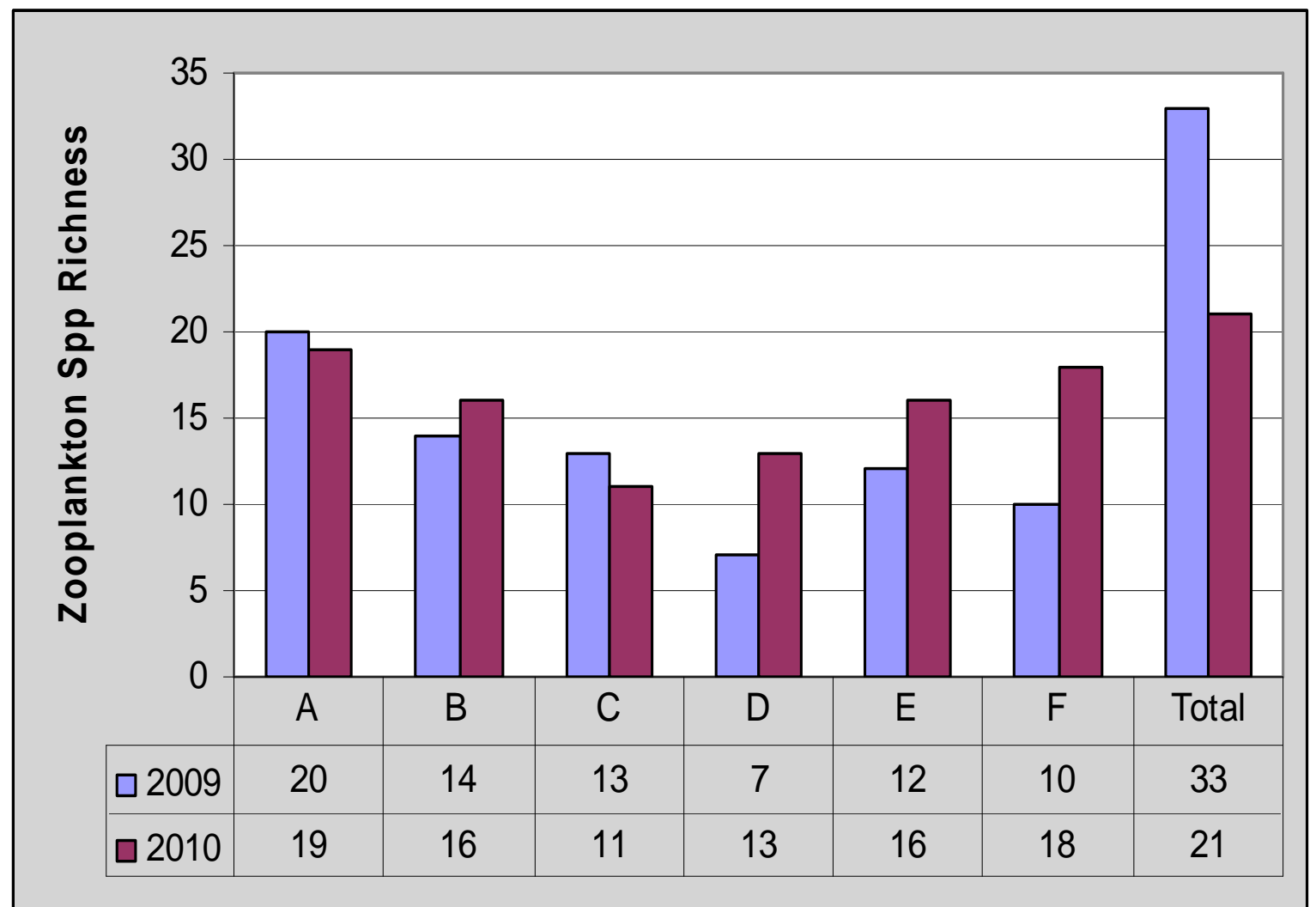

Figure 2: Zooplankton Species Richness of 2009 and 2010 in Bompai-Jakara Catchment Basin, Kano. 


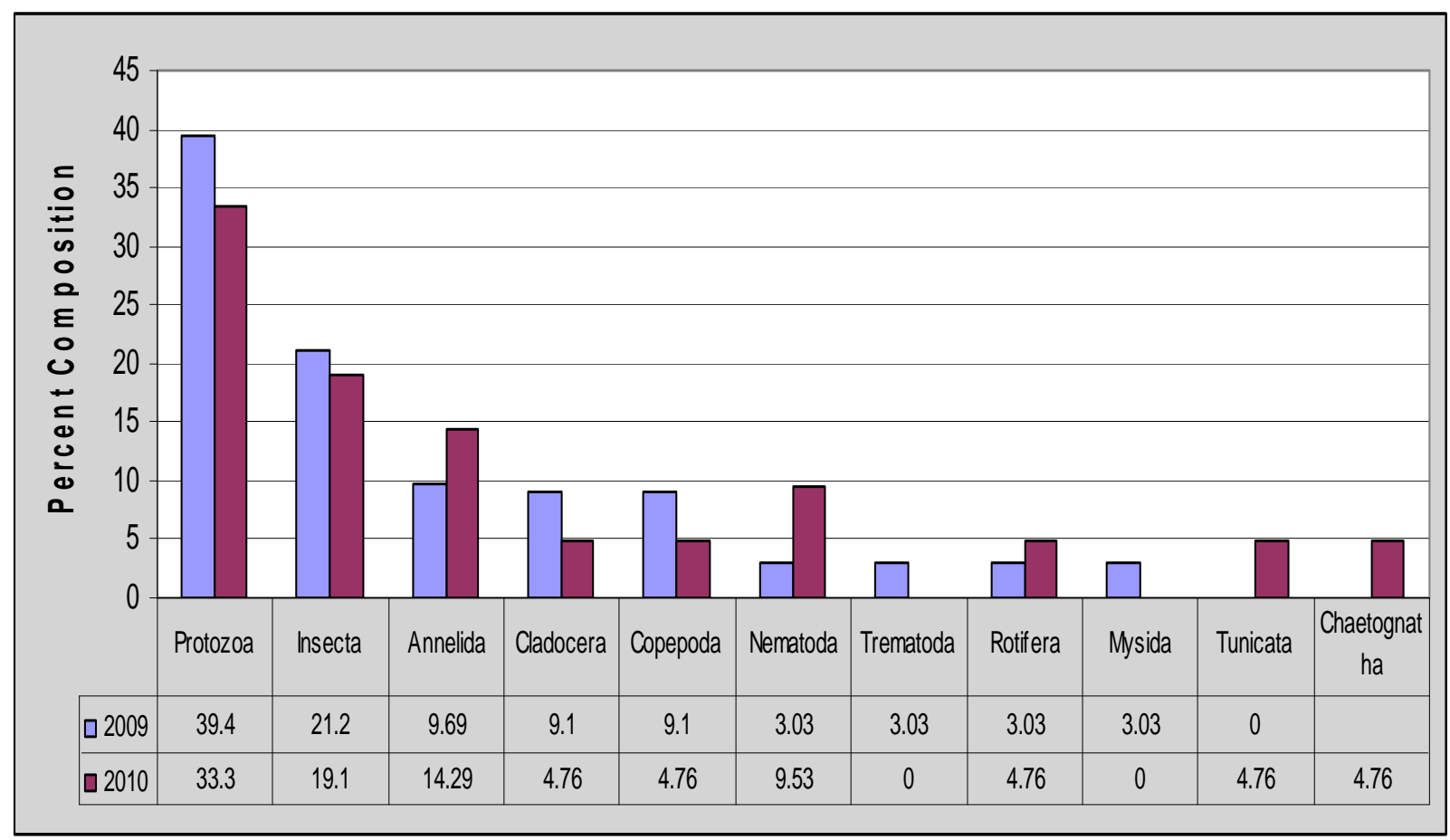

Figure 3: Zooplankton Taxonomic Groups Percentage Composition in 2009 and 2010 in BompaiJakara Catchment Basin, Kano.

\section{DISCUSSION}

Sleigh (1991) explained that there are six ecological factors that are important to life of aquatic organism. They include water, temperature, $\mathrm{pH}$, light, oxygen and salinity. The temperature ranges of BompaiJakara catchment basin are slightly outside the range of $16^{\circ} \mathrm{C}-30^{\circ} \mathrm{C}$ as reported by Chapman (1992) (Table 1). This indicates fluctuations in the water temperature within the study period. Boyd and Frobish (1990) also reported an optimum temperature of $25^{\circ} \mathrm{C}$ $-31^{\circ} \mathrm{C}$ for fish production and the survival of aquatic organisms. Adeniji and Ovie (1982) reported that temperature range for the survival and optimum growth of aquatic organisms is between $22^{\circ} \mathrm{C}$ and $31^{\circ} \mathrm{C}$, also the observed result of water temperature in the basin was within FEPA (1991) and WHO (1999) standard maximum limit of $40^{\circ} \mathrm{C}$. But works conducted in the basin like that of Inuwa (2007) and Mustapha (2008a) agreed with the result obtained in this study, that shows fluctuations in the water temperature within the basin.

The importance of water $\mathrm{pH}$ to the survival of aquatic organisms is great. In freshwater habitats $\mathrm{pH}$ fluctuates based on the metabolic activities as well as the amount of decomposition of organic matter by the microbes. The water $\mathrm{pH}$ obtained in the current study fall within the FEPA (1991), WHO (1999), Pandey (1997) and Ragnar (2004) standard range of 6.0-9.0. It was also in congruence with the findings of Inuwa (2007), Mustapha (2008a) and Mustapha (2008b).

The DO concentrations observed in this study fluctuvaried with the location of sampling, in which low DO was recorded in the Jakara-Getsi River System which is below the normal range stated by FEPA (1991) of $5-7 \mathrm{mg} / \mathrm{L}$, and that of Ragnar (2004) of $\geq 6 \mathrm{mg} / \mathrm{L}$ (Table 1 ). This result agrees with the reports of Inuwa (2007), and Ibrahim (2009), which showed that river system that contain high level of inorganic and organic pollutant tend to have low DO.

The results of $\mathrm{BOD}_{5}$ in this study was within the FEPA (1991) regulated limit and that of Ragnar (2004) of $<4 \mathrm{mg} / \mathrm{L}$ (Table 1 ). The results found in the current study also agreed with the findings of Inuwa (2007) and Ibrahim (2009) conducted in Wasai reservoir (Jakara dam) and Challawa River respectively.

The results of EC in the Jakara-Getsi river system showed higher values than what were obtained in the Wasai reservoir, and were above the maximum standard limit of $2000 \mu \mathrm{S} / \mathrm{cm}$ set out by FEPA (1991) and WHO (1999). The results of previous works conducted by Mustapha (2008a and 2008b) in JakaraGetsi River were in agreement with the finding of the current study, indicating a very high EC above the FEPA and WHO maximum limits. The range of EC recorded in this study was also in congruence with the work reported by Ibrahim (2009) conducted in Challawa River which showed higher EC values above the standard limits.

The result of TDS showed disparate concentrations in respect to location (site) in which Jakara-Getsi River System had higher TDS above maximum limit of $600 \mathrm{mg} / \mathrm{L}$ (Pandey, 1997). In the case of Wasai Reservoir, TDS was found to be within the standard limit. Mustapha (2008b) reported a relatively lower TDS values as opposed what was obtained in this study. Likewise the works of Wakawa (2008) conducted in Challawa River showed lower TDS as compared with that of the Jakara-Getsi River System, but it agreed with what was observed in the Wasai reservoir. 
Transparency enables the sun rays to penetrate to a certain depth enabling photosynthetic flora to perform productive activities, which is very important in the aquatic ecosystem. In the Jakara-Getsi river system, transparency fall below the recommended range of $20 \mathrm{~cm}-40 \mathrm{~cm}$ reported by Chackroff (1978). While in the case of Wasai Reservoir, transparency was within and sometimes above that range (Table 1 ). The result of this study agreed with what was obtained in the work of Ibrahim (2009) and that of Inuwa (2007) which revealed an improvement of water transparency along the basin. This highlight the remediative action taking place along the length of the basin, whereby upstream is the zone of degradation full of debris suspended, and some of them as dissolved solids. As the water reached downstream it reaches zone of

\section{REFERENCES}

Abdullahi, B.A. (1998): The Effect of Temperature on Size and Development in Three Species of Benthic Copepods. Oecolegia. 67: 295-297.

Adeniyi, H.A. and Ovie, S.T. (1982): Study and Appraisal for the Water Quality of the Asa Oil and Niger Rivers. NIFFER Annual Report. P: 15-20.

APHA (2005): Standard Methods for the Examination of Water and Wastewater, $21^{\text {st }}$ edition, eds. Eaton, A.D., Clescer, L.S., Rice, E.W. and Greenberg, A.E. Port City Press, Baltimore, MA, USA, 10: 4-100.

Ayoade, J.O. and Oyelande, B.L. (1992): Water Resources. In: Geography of Nigerian Development. Oguntoyimbo et al. (ed). Heineman, Ibadan, Nigeria. P: 71-88.

Bichi, M.H. (1993): Environmental Pollution in Kano In: The Contribution of Wastewater Discharges from bompai, Sharada, and Challawa industrial estates. Proceeding of Scientific Association of Nigeria, 1993, Bayero University Kano.

Boyd, C.E. and Frobish, L.Y. (1990): Water Quality in Ponds for Aquaculture.Birmingham Publishing Co., Birmingham, UK. P: 5-90.

Chackroff, M. (1978): Freshwater Fish pond Culture and Management. Peace Cone and Volunteers in Technical Assistance, Virginia, USA, pp: 79-92.

Chapman, D. (1992): Water Quality Assessment: A Guide to the use of biota and Water in Environmental Monitoring. Chapman and Hill Publishers Ltd, London. P: 585.

FEPA (1991): National Environmental Protection (Effluent Limitation) Regulations of 1991. Federal Environmental Protection Agency, Lagos, Nigeria. Ref. S.1-8. recovery with marked replenishment of oxygen and increase in transparency (Verma and Agarwal, 2007).

The relative decrease in zooplankton density and richness observed in this study (Table 2; Figures 1,2 and 3 ) with increase in temperature, $\mathrm{pH}$ and TDS, as well as annual progressive decrease in zooplankton abundance and richness indicate an inconvenience due to organic and inorganic pollution of the aquatic system. This stresses the importance of balance in the aquatic ecosystem (Verma and Agarwal, 2007).

\section{CONCLUSION AND RECOMMENDATION}

This study revealed that physicochemical fluctuations was negative impact on the zooplankton species richness and abundance, thus, the need for the government to establish catchment management agency in order to curtail the menace that disrupt the aquatic ecosystem.

Howick, G.L. and Wilhm, J. (1984): Zooplankton and Benthic Macroinvertebrates in Lake Carl Blackwell. Proc. Oklah. Acad. Scie. 64: 63-65.

Ibrahim, S. (2009): A Survey of Zooplankton Diversity of Challawa River, Kano and Evaluation of Some of its Physicochemical Conditions. BAJOPAS. 2 (1): 19-26.

Imam, T.S. (2010): Aspects of Ecology and Biomonitoring of Heavy Metals -Associated with Industrial Pollution in the Bompai-Jakara Catchment Basin, Kano state, Nigeria. PhD Progress Seminar Presented at Biological Sciences Department, Bayero University Kano on $24^{\text {th }}$ February, 2010 (Unpublished).

Imam, T.S. (2011): Monitoring Water Quality Using Zooplanktonic Fauna as Bioindicators at Wasai Reservoir, Kano State, Northern Nigeria. BEST Journal, 8(1):219-225.

Inuwa, B. (2007): Studies on Aspects of Physicochemical Conditions and the Fish Biology in Jakara Dam, Kano, Nigeria. A M.Sc. Dissertation Submitted to the Biological Sciences Department, Bayero University, Kano (Unpublished).

Kabiru, A. (2007): The Physical Environment. Department of Geography, Bayero University, Kano, Nigeria. http://www.kanoonline.com. Accessed on 12/01/2008.

Kolb, J. A. (1986): Marine Biology and Oceanography Grades 9-12, Marine Science Project. FOR SEA. Marine science Center, Poulsbo, WA, p: 1-5.

Lead Technologies Inc. (2002). SPSS for WindowsSPSS Version 15. US.

Markovich, Z. (2003): Ishrana Sarana u Poluintenzivnom Sistemu Gajernja. Zbornik Predavanya, Pastrmsko I Saransko Ribarstio. Poljoprivredni Fakultet, Univerziteta u Beogradu I 'Akraforsk' institu of Aquaculture Res. As. Norway, Beograd, 107-112. 
Mustapha, A. (2008a): Environmental Pollution in Kano: The Contribution of Wastewater Discharge from Kano Old City and Bompai Industrial Estate to Jakara River Basin System, Techno Science J. 2(1): 83-88.

Mustapha, A. (2008b): An Assessment of the Suitability of Water in Jakara-Getsi River System, For Fadama Production at the Kano Region, Kano State, Techno Science J. 1(1): 118-124.

Pandey, G.N. (1997): Environmental Management. Vikas Publishing House, New Delhi, India. P: 33-37.

Ragnar, R. (2004): Environmental Load, CharnetAquafarmer, accessed 05.08.2009.

Sleigh, M. (1991): Protozoa and Other Protists. $1^{\text {st }}$ edition, Cambridge University Press, UK. P: 50-288.

Smashktin, V.,Arunachalam, M. and Behra, S. (2007): Developing Procedures for Assessment of Ecological Status of Indian River Basins in the
Context of Environmental Water Requirements. IWMI Research Report 114, International Water Manangement Institute, Colombo, Sri Lanka.

Verma, P.S. and Agarwal, V.K. (2007): Environmental Biology: Principles of Ecology. $11^{\text {th }}$ reprinted edition. S.Chand \& Co. Ltd. P: 3-500.

Wakawa, J.R. (2008): Impact Assessment of Effluent Discharge on Physicochemical Parameters and Some Heavy Metal Concentrations in Surface Water of River Challawa, Kano, Nigeria. Afric. J. Pur. App. Chem.2 (10): 100106.

WHO (1999): Limits for Effluents Discharge into Surface Waters. World Health Organization, Geneva, $\mathrm{CH}$.

Yamaguchi, E. and Bell, C. (2007): Zooplankton Identification Guide, The University of Georgia Marine Education Center and Aquarium, http://www.marex.uga.edu/aquarium, pp: 12. 